Научная статья

УДК 800

DOI 10.18101/2686-7095-2021-2-26-30

\title{
ИЗОБРАЗИТЕЛЬНЫЕ ЛЕКСИЧЕСКИЕ И СИНТАКСИЧЕСКИЕ СРЕДСТВА В ХУДОЖЕСТВЕННОМ ПРОСТРАНСТВЕ РОМАНА-ХРОНИКИ А. М. АМУР-САНАНА «МУДРЕШКИН СЫН»
}

\author{
(C) Есенова Галина Борисовна \\ аспирант, \\ Калмыцкий государственный университет им. Б. Б. Городовикова \\ Россия, 358000, г. Элиста, ул. Пушкина, 11 \\ esenina.gb@gmail.com
}

\begin{abstract}
Аннотация. В статье исследуются лексические и синтаксические средства в художественном пространстве романа-хроники «Мудрешкин сын», написанного в 1925 г. на русском языке основоположником современной калмыцкой литературы А. М. АмурСананом. Автобиографический роман воссоздает панораму калмыцкой действительности конца XIX - начала XX в.: материальную и духовную жизнь, поведение представителей разных слоев традиционного калмыцкого общества, изменение привычного уклада и привычек людей в ходе общественно-политических изменений (революция, гражданская война, утверждение советской власти). Средства русского языка послужили для писателя благодатным материалом для пропаганды новой жизни, приобщения калмыков к происходящим переменам. Выразительно-изобразительные средства лексики (синонимы, антонимы, лексические повторы) и синтаксиса (ряды однородных членов, парцелляции, риторические вопросы, риторические восклицания, номинативные предложения, вопросно-ответные конструкции и т. д.) создают эмоциональный фон художественного текста, воздействуя на когнитивную и эмоциональную сферу читателя.
\end{abstract}

Ключевые слова: роман-хроника «Мудрешкин сын», А. М. Амур-Санан, лексические, синтаксические изобразительно-выразительные средства, русский язык, калмыки

\section{Для цитирования}

Есенова Г. Б. Изобразительные лексические и синтаксические средства в художественном пространстве романа-хроники А. М. Амур-Санана «Мудрешкин сын» // Вестник Бурятского государственного университета. Филология. 2021. Вып. 2. С. 2630 .

Художественное наследие основоположника современной калмыцкой литературы А. М. Амур-Санана до сих пор тщательно не изучено, хотя его деятельность $[9 ; 18 ; 13 ; 14 ; 3 ; 16 ; 2 ; 8 ; 17 ; 10 ; 6]$ и творческий портрет $[4 ; 5 ; 12]$ были объектом научного исследования. Особый интерес представляет литературное творчество А. М. Амур-Санана. Анализ научной литературы, посвященной художественному наследию А. М. Амур-Санана, позволяет заключить, что до сих пор литературное творчество писателя рассматривалось только с литературоведческой точки зрения, в частности, изучались сюжет, композиция романа-хроники «Мудрешкин сын». К сожалению, не предпринималось лингвистическое исследование ни творчества А. М. Амур-Санана, ни романа-хроники «Мудрешкин сын». Литературная деятельность А. М. Амур-Санана не рассматривалась в аспекте художественного билингвизма, хотя его произведения были созданы в первой трети 
Г. Б. Есенова. Изобразительные лексические и синтаксические средства в художественном пространстве романа-хроники А. М. Амур-Санана «Мудрешкин сын»

XX в. и А. М. Амур-Санана можно отнести к родоначальникам художественного русско-национального билингвизма. Не предпринимается лингвокультурологическое исследование наследия А. М. Амур-Санана, не изучается русскоязычное литературное творчество писателя с точки зрения отражения картины мира калмыков в средствах приобретенной лингвокультуры, хотя в романе-хронике «Мудрешкин сын», по оценке критиков, нарисована панорама традиционной жизни калмыков $[8 ; 15 ; 12]$. К сожалению, до сих пор роман-хроника А. М. Амур-Санана подробно не изучался и с точки зрения языковых особенностей, за исключением исследования функционирования безэквивалентной [11] и национально-региональной [7] лексики в художественном пространстве романа.

Целью настоящей статьи является изучение изобразительных лексических и синтаксических средств в тексте романа-хроники А. М. Амур-Санана «Мудрешкин сын» [1].

Анализ показывает, что изобразительно-выразительные средства русского языка писатель широко использует при описании картин природы, для характеристики персонажей, происходящих событий, а также для передачи переживаемых чувств, эмоциональной оценки поступков, поведения, обычаев. Особенно часто автор использует разнообразные лексические средства. Это могут быть контекстуальные синонимы (тихо и бессильно мычала - о корове; мильй, хороиий, добрый, умный - о сян (хорошем) человеке; обе сироты, обе презираемые, обе несчастные - о матери и Ботохэ), лексические повторы, с помощью которых дается эмоционально-экспрессивная оценка (дорога все хуже и хуже, путь все труднее и труднее - о переходе в осеннюю распутицу). Антонимы могут употребляться для создания контраста, например для характеристики отца: трезвый, в здравом уме, он тиранил нас, а пьяный истязал безумно. Автор часто использует цепочки однородных членов, каждый последующий член которых усиливает передаваемое значение, создавая определенный эмоциональный фон контекста: отеи бил меня, мать, сестер так, как бил нашу рыљую кобылу, безрогую корову и старую собаку; она делает все: стряпает, стирает, обшивает семью, доит и поит коров, сюда входят отеи и мать мужа, все деды, прадеды и вообще все дяди, тети, старшие братья, их жены, сестры и их мужья (о соблюдении обычая избегания замужней калмычкой в отношении родственников мужа); смотря по степени провинности молодайки, приносятся в жертву духам халаmbl, деньги, бараны, даже лошади и коровы. Иногда для усиления воздействующей силы текста в одном предложении автор использует и лексический повтор, и контекстуальные синонимы, например: только потому что она - детище родового общества, детище бедности и нужды. Зачастую автор прибегает к комбинированию средств. Например, использует лексический повтор, контекстуальные синонимы, ряды однородных членов: невольно вспомнилось мне мое горемычное прошлое, мое скорбное детство: такая же убогая кибитка, моя бедная плачущая мать, вечно обижаемый и вечно обижающий свою семью, всегда горько пьяный отец. Автор может прибегать к контекстуальным синонимам и сравнениям, например: мои маленькие, забитые, запуганные насмерть, как звереныши, сестры. Все эти средства служат передаче замысла автора, используются для воздействия на эмоциональную сферу читателя.

К синтаксическим изобразительно-выразительным средствам, которые используются автором в тексте романа, относятся риторические вопросы и воскли- 
цания, вопросно-ответные конструкции, назывные предложения, ряды синтаксически однородных конструкций, парцеллированные конструкции. Большая эмоционально-экспрессивная нагрузка лежит на риторических вопросах, которые задает автор себе в самые сложные моменты жизни. Например: $A$ что тогда станет с нами - со мной, с бабушкой Алдэ, с отияом? Что было делать? Риторические вопросы в тексте произведения используются реже, чем риторические восклицания, с помощью которых автор передает всю глубину переживаемых чувств (Сколько раз было так! — о побоях пьяницы-отца), свою эмоциональную оценку происходящему (Проклятый обычай проклятого родового быта, отживщего, но живучего и мешающего жить новым поколениям! Сколько было тут вывернутых наизнанку, до неузнаваемости, под иявет и тон революционного времени, индалуков! Сколько бездельников, пропойц, зубоскалов, воров и моченников - людей, способных с величайшим усердием показать вид общественно полезных работников, но по существу своему глубоко антиобщественных, вредHblx!). Риторические восклицания могут адресоваться и самому героюрассказчику: Ах, только бы скорее вырасти! Да, надо во что бы то ни стало сделаться сян-кюном!

Подобные синтаксические средства могут передавать глубокие чувства любви, нежности к двум самым любимым существам - матери (Так безгранична любовь матери!) и бабушке (Сколько прекрасных сказок она мне рассказала!). Особой эмоциональной силой нагружены конструкции с прямой речью, вложенные в уста маленького мальчика: «Сколько раз я плакал и думал: "Неужели никогда не придет сян-кюн и не скажет, что так жить нельзя и не заступится за нас?"». Поиску ответа на этот вопрос он посвящает свою жизнь. В связи с этим данная конструкция наделяется значительной смысловой нагрузкой в художественном пространстве романа-хроники. Разлитой экспрессивности текста способствуют и эмоционально-оценочные вводные конструкции, например: Я купил три ведра водки - будь она проклята! - и посещение сестры состоялось.

Вопросно-ответные конструкции являются средством передачи внутренней речи, передают размышления автобиографического героя, его сомнения: «Значит, недостаточно вырасти, чтобы стать сян-кюном. Для этого надо что-то еще. Что же? Вероятно, надо учиться». Прямая речь также служит особой эмоциональности изложения: «Как бы хорошо мне надеть такой мундир, учиться и узнать все, - мечтал я».

Следующее выразительное синтаксическое средство - назывные предложения, которые используются реже, чем рассмотренные выше, однако они используются автором в особо значимых эпизодах. Так, предложением Группа кибиток начинается рассказ о Бадгэ.

Автор использует и такое изобразительное средство, как синтаксически однородные конструкции: Мои маленькие, забитые, запуганные насмерть, как зверенылии, сестры. Хромая, вечно голодная рыжая кобыла. Худые от недоедания коровы...Всегда голодная, с опаленной шерстью на боках, старая, но верная собака, тоскливо полулежавшая около очага и вместе со всеми нами смотревшая в рот отиу... Здесь они усиливают воздействующую силу назывных конструкций.

Некоторый налет разговорности привносят в художественный текст парцеллированные конструкции, например: Я же ходил голодный и оборванный. Главное - голодный; И хоть бы раз он дал этому сыну леденеи, хоть бы раз приласкал его. Никогда! И тут впечатлительный ребенок искал вместо своего род- 
Г. Б. Есенова. Изобразительные лексические и синтаксические средства в художественном пространстве романа-хроники А. М. Амур-Санана «Мудрешкин сын»

ственника чужсго. Чужсог, но хорошего человека - сян-кюна. Употребление подобных конструкций уместно: они не нарушают стилистическое единство контекста, а передаваемая через них экспрессия свидетельствует об оправданности их использования в художественном пространстве романа.

Таким образом, проведенный анализ позволяет заключить, что в романехронике А. М. Амур-Санана «Мудрешкин сын» широко используются разнообразные лексические и синтаксические изобразительно-выразительные средства. Синонимы, антонимы, лексические повторы, ряды однородных членов, парцелляции, риторические вопросы, риторические восклицания, номинативные предложения, вопросно-ответные конструкции, синтаксически однородные конструкции создают эмоциональный фон художественного текста, воздействуя на когнитивную и эмоциональную сферу читателя.

Литература

1. Амур-Санан А. М. Мудрешкин сын. Москва: Советский писатель, 1966. 456 с.

2. Балакаев А. Г., Оглаев Ю. О. Литературное наследие А. Амур-Санана: проблемы публикации // А. М. Амур-Санан - певец революции: к 100-летию со дня рождения. Элиста: Изд-во КНИИФЭ, 1988. С. 113-125. Текст: непосредственный.

3. Джамбинова Р. А. А. Амур-Санан и калмыцкая литература // А. М. Амур-Санан певец революции: к 100-летию со дня рождения. Элиста: Изд-во КНИИФЭ, 1988. С. 2645. Текст: непосредственный.

4. Джимгиров М. Э. А. М. Амур-Санан (1888-1939) // Вестник КНИИЯЛИ. 1973. № 8. С. 8-21. Текст: непосредственный.

5. Есенова Т. С. Русский язык в Калмыкии. Элиста: Изд-во КалмГУ, 2003. 190 с. Текст: непосредственный.

6. Есенова Г. Б., Джалсанов Ц. С. Наследие А. М. Амур-Санана // Трудовой вклад народов Юга России в победу в Великой Отечественной войне 1941-1945 гг.: материалы российской научно-практической конференции. Элиста: Изд-во КалмГУ, 2020. С. 240246. Текст: непосредственный.

7. Есенова Т. С., Есенова Г. Б. Функционирование национально-региональной лексики в художественном тексте // Русский язык в современном научном и образовательном пространстве: материалы международной научной конференции, посвященной 90-летию профессора С. А. Хаврониной. Москва: Изд-во РУДН, 2020. С. 285-290. Текст: непосредственный.

8. Кабаченко Е. Т. Амур-Санан. Жизнь и творчество. Элиста: Калмиздат, 1967. 131 с. Текст: непосредственный.

9. Команджаев А. Н. Путешествие в калмыцкий хотон // Теегин герл. 1988. № 3. С. 97-100. Текст: непосредственный.

10. Лиджиева Б. Б. Концепция личности в творчестве А. М. Амур-Санана // А. М. Амур-Санан - певец революции: к 100-летию со дня рождения. Элиста: Изд-во КНИИФЭ, 1988. С. 80-95. Текст: непосредственный.

11. Манджиева Э. Б., Манджиев Б. П. Безэквивалентная лексика в художественном тексте (на материале романа-хроники А. М. Амур-Санана «Мудрешкин сын») // Русская речь в инонациональном окружении. Элиста, 2019. Вып. 11. С. 31-37. Текст: непосредственный.

12. Мусова Н. Н. А. М. Амур-Санан - публицист // А.М. Амур-Санан - певец революции: к 100-летию со дня рождения. Элиста: Изд-во КНИИФЭ, 1988. С. 64-79. Текст: непосредственный.

13. Неяченко Р. В. А. М. Амур-Санан о судьбе женщины-калмычки // А. М. АмурСанан - певец революции: к 100-летию со дня рождения. Элиста: Изд-во КНИИФЭ, 1988. С. 126-137. Текст: непосредственный. 
14. Поляков Н. Н. Антон Амур-Санан. Элиста: Калмиздат, 1970. 82 с. Текст: непосредственный.

15. Поляков Н. Н. Летописец революции // А. М. Амур-Санан - певец революции: к 100-летию со дня рождения. Элиста: Изд-во КНИИФЭ, 1988. С. 46-64. Текст: непосредственный.

16. Романенко Д. И. О творчестве А. Амур-Санана // Теегин герл. 1963. № 3. С. 57-72. Текст: непосредственный.

17. Салдусова А. Г. Роман А. М. Амур-Санана «Мудрешкин сын» (к проблеме литературного героя) // А. М. Амур-Санан - певец революции: к 100-летию со дня рождения. Элиста: Изд-во КНИИФЭ, 1988. С. 96-112. Текст: непосредственный.

18. Убушаев В. Б. Революционер, писатель, интернационалист // А. М. Амур-Санан певец революции: к 100-летию со дня рождения. Элиста: Изд-во КНИИФЭ, 1988. С. 3-25. Текст: непосредственный.

Статья поступила в редакцию 10.02.2021; одобрена после рецензирования 30.05.2021; принята к публикации 30.06.2021.

\section{VISUAL LEXICAL AND SYNTACTIC MEANS IN ARTISTIC SPACE OF «MUDRESHKIN'S SON» CHRONICLE NOVEL BY A. M. AMUR-SANAN}

Galina B. Esenova

postgraduate student,

Kalmyk State University named after B.B. Gorodovikov

11 Pushkin St., Elista 358000, Russia

esenina.gb@gmail.com

Abstract. The article examines the lexical and syntactic means in the artistic space of the chronicle novel "Mudreshkin's Son", written in Russian in 1925 by the founder of modern Kalmyk literature A.M. Amur-Sanan. The autobiographical novel recreates a panorama of Kalmyk reality in the end of the 19th and beginning of the 20th centuries by showing the material and spiritual life, the behavior of representatives of different strata of traditional Kalmyk society, a change in the habitual way of life and habits of people in the course of social and political changes (revolution, civil war, the establishment of Soviet power). The means of the Russian language served as a fertile material for the writer to propagate a new life, to familiarize the Kalmyks with the ongoing changes. Expressive and pictorial means of vocabulary (synonyms, antonyms, lexical repetitions) and syntax (rows of homogeneous members, parcellations, rhetorical questions, rhetorical exclamations, nominative sentences, question-and-answer constructions, etc.) create an emotional background of a literary text, affecting the cognitive and the emotional sphere of the reader.

Keywords: chronicle novel «Mudreshkin's Son», A. M. Amur-Sanan, lexical, syntactic pictorial and expressive means, Russian language, Kalmyks

For citation

Esenova G. B. Visual lexical and syntactic means in artistic space of «Mudreshkin's Son» chronicle novel by A. M. Amur-Sanan. Bulletin of Buryat State University. Philology. 2021; 1: 26-30 (In Russ.).

The article was submitted 10.02.2021; approved after reviewing 30.05.2021; accepted for publication 30.06.2021. 